\title{
Cikkismertetés: Az egyéni választáson túl
}

\section{Article review: Moving beyond individual choice in policies to reduce health inequalities}

$\begin{array}{ll}\text { Ismertető: } & \text { Csizmadia Péter } \square \\ & \text { Nemzeti Népegészségügyi Központ }\end{array}$

Ismertetett cikk: Kriznik NM, Kinmonth AL, Ling T, Kelly MP. Moving beyond individual choice in policies to reduce health inequalities: the integration of dynamic with individual explanations. J Public Health (Oxf). 2018 Dec 1;40(4):764-775. doi: 10.1093/pubmed/fdy045

Beküldve: $\quad$ 2019.12. 09.

doi: $\quad$ 10.24365/ef.v61i1.547

Kulcsszavak: egészségegyenlőtlenségek

Keywords: health inequalities

\section{BEVEZETÉS}

A fenti cikk bevezetésében a szerzők megállapítják, hogy az Egyesült Királyság jelenlegi, egészségegyenlőtlenségek csökkentését célzó népegészségügyi szakpolitikája egyéni megközelítésen alapul. E nézőpont szerint az emberi viselkedés az egészségi állapot döntő tényezője, az egészségmagatartás nagyrészt egyéni választás kérdése, vagyis elsősorban az egyének felelősek saját egészségükért és magatartásváltoztatásukért.

A szerzők véleménye szerint az ilyen egyszerü, lineáris ok-okozati magyarázatok és a közvetlen kockázati tényezők szerepének túlhangsúlyozása oda vezet, hogy a megbetegedések kialakulását megelőzendő, a népegészségügy feladatának az egyéni magatartásváltoztatást tartjuk.

A cikk írói amellett érvelnek, hogy a kérdés ennél jóval bonyolultabb, az egyéni tényezőkön túl a különböző faktorok közötti kölcsönhatást és a dinamika egészségre gyakorolt hatását is figyelembe kell venni.
Úgy vélik, hogy számos tudományág (biológia, filozófia, neurológia, pszichológia, szociológia és történelemtudomány) bizonyítékokat szolgáltatott további lehetséges mechanizmusok létezésére. A biológia új felfedezései mind az epigenetika, mind pedig a végrehajtó múködés neuropszichológiája terén olyan fontos és új eredményeket hoztak napvilágra, melyek hozzájárulnak az egészségegyenlőtlenségek fenntartásához, ám kívül esnek a jelenlegi szakpolitikai érdeklődésen.

A tanulmányban elemzett hat dokumentum bizonyítja, hogy az egészségegyenlőtlenségek csökkentésére szolgáló beavatkozások alaptételei az 1970-es évek közepe óta nem változtak jelentősen: továbbra is az egyéni felelősségvállalásra koncentrálnak.

Ezt az állandóságot kiemelve a szerzők javaslatot tesznek olyan lépések megtételére, amelyek lehetővé teszik a domináns nézőpont alternatív megközelítését. Úgy vélik, hogy a dinamikus, relációs felfogás elfogadása alapvető fontosságú az ok-okozati mechanizmusok teljesebb megértéséhez, valamint 
az egészségegyenlőtlenségek kezelésére szolgáló hatékonyabb beavatkozások megtervezéséhez és végrehajtásához. A dohányzás visszaszorításának sikere az Egyesült Királyságban a dohányzáshoz kapcsolódó gyakorlatok dinamikus és relációs megközelítésének köszönhető. Ez magában foglalja az egyéni tényezőket, és azon túl mind a piacok, mind a reklám szerepét, valamint a dohányipar „piszkos trükkjei” ellen irányuló határozott fellépést. A dinamikus kifejezés az időben bekövetkező változásokra utal, míg a relációs viszonyok alatt azt kell érteni, hogy jelent esetben figyelembe kell venni a dohányzás kapcsolati hálóját, ami túlmutat az egyénen és a cigaretta elszívásán.

Ebben a megközelítésben három téma játszik központi szerepet:

- a hatalmi viszonyok feltárása, a társadalmi csoportok és intézmények közötti kapcsolatok leírása;

- a „történetiség”, vagyis annak vizsgálata, hogy a kapcsolatok miként változnak vagy maradnak fenn az időben;

- és a "dinamika”, amely a biológiai és társadalmi tényezők közötti időbeli kapcsolatra utal.

A szerzők először bizonyítékokat azonosítottak a relációs és dinamikus tényezők fontosságáról az egészségegyenlőtlenségek problémájának megértésében. Másodszor, az egészségegyenlőtlenségekre vonatkozó, évtizedek óta alkalmazott szakpolitikai megközelítéseket vizsgálták, bemutatva az egyéni magatartásváltozásra helyezett hangsúlyt. Végül olyan kérdéscsoportot dolgoztak ki, amely kiemeli ezt a tágabb perspektívát, hogy érzékenyítse a szakpolitikai döntéshozókat, a szolgáltatások fejlesztőit és a kutatókat, amikor az egészségegyenlőtlenségek kezelésére irányuló szakpolitikákat dolgoznak ki.

\section{HATALOM}

Az egészségegyenlőtlenségekkel foglalkozó dokumentumok a fennálló helyzetre ritkán tekintenek a politikai hatalmi viszonyok eredőjeként, vagy az osztályok, nemek és etnikai csoportok közötti versenyként a szúkös erőforrásokhoz való hozzáférésért, vagy a hatalmi viszonyoknak az egészségre gyakorolt mechanikus következményeiként. A legtöbb politikai javaslat központi tétele az egyén egészségesebb választáshoz való „hozzásegítése, felhatalmazása", de a csoportok és intézmények közötti hatalmi dinamika hatásait figyelmen kívül hagyják vagy alulértékelik. A hatalmi viszonyok a társadalomi élet részét képezik, alapvetően befolyásolják az egyének erőforrásokhoz való hozzáférését - ideértve az egészségügyi szolgáltatásokat is -, valamint definiálják a diszkrimináció, a hátrányos helyzet, a zaklatás és a társadalmi kirekesztés fogalmait, amelyek befolyásolják az oktatási és foglalkoztatási lehetőségeket. Ezen összefüggések és az egészségegyenlőtlenségekhez fűződő kapcsolatuk évtizedek óta ismertek, ám az egyének életére gyakorolt közvetlen hatásukat nem említik a kormányzati politikai dokumentumok.

\section{TÖRTÉNELMI PERSPEKTÍVA}

Hasonlóképpen, a történelemi és a távlati gondolkodás nagyrészt hiányzik az egészségegyenlőtlenségekkel kapcsolatos politikai diskurzusból. A történelem a XIX. század óta a népegészségügyi haladásról szóló narratívává vált. A politikában nyilvánvaló az intézményi emlékezetvesztés, vagyis viszonylag rövid idő alatt a hasonló ötletek újbóli felfedezése és újrahasznosítása. A jelenlegi szakpolitikák annak a történelmi amnéziának a bizonyítékai, amelyek a jelenlegi egészségegyenlőtlenségekhez vezettek. Ebből adódik az a feltevés, hogy az egészségegyenlőtlenségek csak a jelenlegi társadalmi feltételekkel magyarázhatóak, figyelmen kívül hagyva az akár évtizedek óta fennálló endemikus társadalmi struktúrákat. Ez a nézőpont az egészségbeavatkozások sikerével kapcsolatban túlzottan optimista elvárásokhoz vezet, ahol a gyors megtérülés elsődleges követelmény. Ha az intézkedések nem járnak gyors eredménnyel, akkor a népegészségügyi kezdeményezések politikai támogatottsága erősen visszaeshet. A politika és a kutatás történelmi perspektívája tisztázza az egészségegyenlőtlenségek hosszabb távú továbbélésének és újratermelődésének okait. Raadschelders szerint túlságosan gyakran tekintenek a „történelemre” olyan „múltként”, amely feljegyezhető, de kevés jelentőséggel bír a kortárs kihívások szempontjából. A történelemnek ez a csökkentett és gyenge időérzete oda vezet, hogy a múltra olyan események sorozataként tekintenek, amely lineáris módon, elkerülhetetlenül vezet a jelenhez. A szerzők szerint a történeti perspektíva gazdagabb értelmezési lehetőséget nyújt, mint az 
ok-okozati összefüggések, segítségével felismerhető, hogy a múlt miként hagy nyomot az egészségegyenlőtlenségek időbeli újratermelődésében. Ez a nézőpont segít megvilágítani a politikai döntéshozók számára rendelkezésre álló azon lehetséges eszközöket és beavatkozásokat, amelyek tartós hatással bírhatnak az egészségegyenlőtlenségek szempontjából.

\section{BIOLÓGIAI ÉS TÁRSADALMI TÉNYEZŐK}

A biológiai és a társadalmi tényezők egymással való kölcsönhatását előbb Engel, majd Barker mutatta be. Az epigenetika új bizonyítékokat szolgáltat az egészségegyenlőtlenségek nemzedékeken átívelő hatására, amit a társadalmi-gazdasági körülmények enyhíthetnek vagy súlyosbíthatnak. Mindezek alapján javasolt, hogy ismételten nagy hangsúlyt helyezzünk az anyai, magzati és gyermeki egészséget támogató programokra, melyek kulcsfontosságú stratégiaként segithetik az egészségegyenlőtlenségek csökkentését.

\section{SZAKPOLITIKA}

A kutatók áttekintették az egészségegyenlőtlenségek kezelésére szolgáló, az Egyesült Királyság kormánya vagy egészségügyi minisztériuma által 1976 és 2010 között közzétett hat kulcsfontosságú szakpolitikai dokumentumot. Megállapították, hogy az egészségegyenlőtlenségek csökkentésére és a nem fertőző betegségek megelőzésére irányuló stratégiák továbbra is az egyéni magatartásváltoztatásra koncentrálnak. Az időben egymást követő dokumentumok egyre gyakrabban utalnak számos egyéb tényező (társadalmi, kulturális, gazdasági és környezeti) egészségre gyakorolt hatására is, ennek ellenére ezeket ritkán használták fel a szakpolitika, a beavatkozások és a programok kidolgozásakor.

Például a „Mentsünk életeket: az egészségesebb nemzetért" (Saving Lives: Our Healthier Nation) akcióterv érvelése szerint „a rossz egészségi állapot oka sokféle: a személyes, társadalmi, gazdasági és környezeti tényezők komplex kölcsönhatása". $A z$ egészségegyenlőtlenségek csökkentésének fő eszköze e nézet szerint az, hogy az egyének tájékozódjanak az egészségüket érintő kockázatokról, mivel „a legtöbb esetben az egyén dönt a kockázat vállalásáról". A legkevésbé vagy kevésbé kockázatos döntés meghozataláért az egyén felel. Itt tehát megszakad a kapcsolat a betegségek okairól szóló szakpolitikai retorika és az ajánlott fejlesztő intézkedések között.

\section{AZ EGÉSZSÉGET MEGHATÁROZÓ TÉNYEZŐK ÉS AZ EGYÉNI EGÉSZSÉGMAGATARTÁS VISZONYA}

Az egészséget meghatározó tágabb tényezők fontosságát hangsúlyozó, az egészségegyenlőtlenségekkel kapcsolatos beavatkozások gyakran paradox módon az egyéni viselkedésre koncentrálnak. Ahelyett, hogy az egészségdeterminánsok szerepét hangsúlyoznák, bizonyos csoportokra úgy tekintenek, hogy nem képesek sikeresen megküzdeni e tényezők hatásaival, ezt bizonyítja az egészségre káros döntéseik meghozatala. Így számos beavatkozás olyan lehetőségek biztosítására összpontosít, amelyek lehetővé teszik az egyén számára, hogy például oktatás, képzés és munkalehetőségek révén - javítsa jelenlegi társadalmi és gazdasági helyzetét. Általános érv, hogy ezen lehetőségek megragadásával az egyének nagyobb ellenőrzést nyernek életük felett, ami segitheti, hogy jobban érdeklődjenek egészségük iránt, több egészséges döntést hozzanak. Ezeket a narratívákat „az egyén, aki választ a felkínált lehetőségek közül" elképzelés dominálja. A tézis szerint a probléma egyéni, viszont az egyének önmagukban nem képesek egészséget támogató döntéseket hozni, kivéve, ha olyan beavatkozások segítik őket, amelyek megváltoztatják tulajdonságaikat, így magatartásukat is.

Az egyénre való összpontosítás semlegesíti a társadalmi felelősségvállalást, emellett számos fontos szereplőt és intézményt - különösképp az államot, a piacokat és az ipart - kiretusál a képből. Tehát a neoliberális gondolkodásból fakadó állami szerepvállalás csökkentése, a piac szerepének hangsúlyozása (ami inkább oka, mint megoldása a problémának), valamint az élelmiszer-, reklám- és alkoholipar (esetleges) egészségkárosító hatásai így kényelmesen egy táborba kerülnek.

Az ezeket a szereplőket megcélozó és befolyásolni kívánó kezdeményezések nem játszanak központi szerepet a jelenlegi szakpolitikában. Az a vélemény, ami szerint az állam kötelessége mindenki számára a lehető legnagyobb mértékben biztosítani az egészséges élethez való esélyt, csökkenteni a 
hátrányos helyzetű csoportokat és egyéneket érintő egészségegyenlőtlenségeket - ideértve az arányos szabályozási környezet kialakítását is -, ritkán volt domináns motívum a szakpolitikai dokumentumokban. Sen szerint foglalkozni kell azzal, hogy a köz- és magánjogi akciók, valamint a különböző szervezetek hogyan alakítják az egyének képességét az egészségükkel kapcsolatos pozitív döntések meghozatalára. Például az elhízás, ami egyszerre súlyos népegészségügyi probléma és az egészségegyenlőtlenségek egyik fontos oka, az elmúlt másfél évtizedben beágyazódott a politikai diskurzusba. Ez azonban nem volt elegendő az elhízás visszaszorítására. Ennek ellenére meggyőző bizonyítékok vannak arra, hogy az elhízást elősegítő környezet elhízásjárványt idéz elő, és ennek megfékezéséhez a járvány szerkezetére és dinamikájára kell összpontosítani. A szakpolitikai megoldások ehelyett folyamatosan a proximális tényezőkre, leginkább az egyén étrendjére és testmozgására összpontosítanak.

Ennek a perspektívának a legfontosabb kivételét képezte az elhízás elleni küzdelemről szóló, 2007ben közölt jelentés, mely bizonyítékokat mutatott be az elhízás társadalmi és biológiai összetettségérôl, valamint hangsúlyozta az egyéni szinten túli beavatkozás szükségességét és a kutatás fontosságát. Az időközi jelentés 3 évvel később felhívta a figyelmet a felek érdektelenségére, ami akadályozhatja az elhízás kezelésére irányuló jelenlegi és jövőbeli stratégiák, valamint beavatkozások sikerét. Az ajánlások végrehajtását még azelőtt befejezték, hogy a hatásokat megfelelően fel lehetett volna mérni.

Néhány más példa is van a relációs megközelítés alkalmazására, ilyen a National Institute for Health and Care Excellence (NICE) fertőző betegségek etiológiája. Ugyanakkor azért, mert valaki tisztában van a dohányzás okozta egészségkockázatokkal és ismeri az egészségmagatartás, valamint a megbetegedések közötti kapcsolatot, ez magában nem nyújt megoldást a dolgok megváltoztatására.

Például a cigarettafüstnek való kitettség vagy alkoholfogyasztás veszélyeivel kapcsolatos ismeretek azt sugallják, hogy az expozíció csökkentése hasznos lenne, de arra nem adnak választ, hogyan lehet ezt elérni. Az ipar, a piacok, a reklám, az egyéni preferenciák, a csoportmagatartás és az egyes szereplők közötti kapcsolati rendszerek dinamikájára összpontosítva gazdagabb elméleti keretet biztosítható a probléma kezelésére szolgáló integrált programok kidolgozásához és értékeléséhez. Ez volt a titka a dohányzás elleni küzdelem sikerének az Egyesült Királyságban. Egy hasonló, „hogyan kell” megközelítés támogatandó az elhízásjárvány, az alkoholfogyasztás visszaszorításának és a fizikai aktivitás növelésének tekintetében.

\section{A TANULMÁNY LEGFONTOSABB EREDMÉNYEI}

A szerzők kiemelik, hogy az egészségegyenlőtlenségek és az okozati mechanizmusok természetéről az egyéni választáson és felelősségvállaláson túl is léteznek kiterjedt, több tudományágat átfogó bizonyítékok, ám ezek ritkán befolyásolják a megelőző programok kidolgozását.

$A z$ egészségegyenlőtlenségek csökkentésére irányuló beavatkozások továbbra is elsősorban az egyéni viselkedésre összpontosítanak. Ennek ellenére számos tudományág, köztük a biológia, a filozófia, a neurológia, a pszichológia, a szociológia és a történelem, területéről számos, az egészségegyenlőtlenség szempontjából releváns mechanizmus létezéséről rendelkezünk bizonyítékokkal. Ezeket a bizonyítékokat azonban még nem alkalmazzák szisztematikusan a szakpolitikák kidolgozásakor, vagy a beavatkozások tervezésekor.

A tanulmány írói olyan nézőpontot javasolnak, amely felismeri azon rendszerek bonyolultságát, amelyekben a népegészségügynek múködnie kell. A szúk fókuszú, lineáris magatartásváltoztatásra koncentráló modellekről a hangsúlyt inkább a reflexív rendszerekre helyeznék át, az ezekben a rendszerekben megnyilvánuló hatalmi viszonyokra összpontosítva.

Az idézett cikk kiemeli az emberi kapcsolatok és társadalmi csoportok közti viszony vizsgálatának fontosságát. Mivel ezen kapcsolatok múködése idővel változik, a szerzők javasolják, hogy a jelenlegi, egyéni magatartásváltozásra fókuszáló szemléletről szóló diskurzus szélesebb perspektívába kerüljön, felismerve a hatalom, az idő, valamint a biológiai és társadalmi tényezők közti kapcsolatokat.

Megállapítható, hogy a jelenlegi, egészségegyenlőtlenségek csökkentését szolgáló szakpolitikák nem hatékonyak, mert a nem fertőző betegségek megelőzését az egyéni magatartásváltoztatáson keresztül célozzák meg.

A szerzők szerint ez a nézőpont korlátozza a szakpolitikák és a beavatkozások hatását. A programok 
elsősorban az egyéni magatartásváltoztatásra koncentrálnak, előtérbe helyezve az egyéni választást és felelősséget. Erős és széles körű bizonyítékok állnak rendelkezésre arra vonatkozóan, hogy az egymást összekötő és az egymással kölcsönhatásba lépő tényezők - az egyénen túl is - generációkon át befolyásolják az egészségi állapotot, ideértve a lakhelyet, a környezetet, a hatalmat, a gazdaságot, az intézményi kapcsolatokat és a biológiát. Ezen bizonyítékok léte annak ellenére sem volt elegendő a politikai támogatás megszerzéséhez, hogy a meglévő stratégiák nem tudták sikeresen kezelni az egészségegyenlőtlenségeket.
A cikkírók olyan kérdések megfogalmazását javasolják, amelyeket a kutatók és a politikai döntéshozók felhasználhatnak az új szakpolitikák kialakításakor vagy a korábbiak kritikája során, így ez a tágabb megközelítésmód ismertebbé válhat. Ez a lépés segítheti a teljes körű beavatkozások retorikájától a hosszú távú beavatkozások megvalósításáig és értékeléséig az egészségegyenlőtlenségek problémájának feltárását és a kezelésükre szolgáló szakpolitikák kidolgozását.

\section{TANULSÁGOK A HAZAI SZAKEMBEREK SZÁMÁRA}

A brit példához hasonlóan a jelenlegi, hazai felfogás is elsősorban egyéni megközelítésen keresztül vizsgálja az egészségegyenlőtlenségek problematikáját, vagyis az emberi viselkedés az egészségi állapot döntő tényezője, az egészségmagatartás nagyrészt egyéni választás kérdése, tehát elsősorban az egyének felelősek saját egészségükért és magatartásváltoztatásukért.

A hazai ok-okozati mechanizmusok teljesebb megértése lenne szükséges az egészségegyenlőtlenségek kezelésére szolgáló hatékonyabb beavatkozások megtervezéséhez és végrehajtásához. 